\title{
what about capitalism? jürgen habermas's project of a european democracy
}

\author{
wolfgang streeck \\ Max-Planck-Institut für Gesellschaftsforschung, Paulstraße 3, Köln 50676, Germany \\ E-mail: ws@mpifg.de
}

doi:10.1057/eps.2016.3; published online 15 April 2016

\section{Book reviewed: \\ The Lure of Technocracy}

Jürgen Habermas's, trans. Ciaran Cronin (Cambridge: Polity, 2015), 176 pp., ISBN: 978-0745686813

$\mathrm{T}$ he book to be reviewed here - The Lure of Technocracy - is Jürgen Habermas's latest statement on Europe, its crisis, its politics and its prospects. It is the English translation a remarkably good one - of Im Sog der Technokratie (Habermas, 2013). The German original came out as Volume XII of Kleine politische Schriften, a series that dates back to 1980 and which, according to Habermas (2013:10), it is to conclude. The twelve volumes, all of them collections of occasional papers, interviews and public lectures produced alongside Habermas's main works, have long become an object of wide admiration, in Germany and beyond, for their unique combination of political activism, profound scholarship and, not least, brilliant essayistic prose, and they can already now claim a prominent place in the political and cultural history of postwar Germany. The Lure of Technocracy consists of ten pieces from the last 3 or 4 years, seven of them more or less directly concerned with European integration and its crisis since $2008 .^{1}$ The three remaining chapters, assembled under the title German Jews, Germans and Jews, are indispensable reading for anyone interested in West German intellectual life after 1945. Although they stand for an important subtheme of Habermas's Europeanism, I will focus on the seven Chapters that precede them.

Habermas's European writings are inextricably linked into his sociological and philosophical scholarship as it has developed since the 1960s. One may even go as far as to say that how 'Europe' will fare 
will be a test of whether or not Habermasian general theory of human and moral evolution actually 'works'. Indeed Habermas, one of the foremost public intellectuals in Europe and beyond, may have become as active a political agent as he is in the battles over the future constitution of Europe precisely because his stake in their outcome is so high. A book review, short as it must be, cannot possibly pursue the manifold theoretical ramifications that inform a political vision as carefully calibrated as this one to fit an immensely ambitious general perspective on history and society. On the other hand, criticizing Habermas simply on empirical grounds is not enough, if only because his work is not just about the factual but also, and most importantly, about the presumably possible - placing the critic at risk of appearing as a petty priest of a dogmatic cult of the superficially real assaulting a prophet of a higher truth.

The Lure of Technocracy may legitimately be read as a summary of long years of scholarly reflection and public intervention on its subject, indicating where the theoretical-political project it represents - a project occasionally called upon by the Brussels Eurocracy for ideological legitimation purposes - has today arrived. Looked at this way, however, the book gives its readers reasons for concern. To begin with, its chapters never discuss the nature of the economic interests and conflicts underlying the contemporary politics of Europe and European integration - suggesting, as though this was still the social-democratic 1980s or the Third Way 1990s, that a future European democracy enshrined in a European constitution will as a matter of course come with a primacy of European politics over European and, indeed, global capitalism. The book also misconceives the role of European Monetary Union, presenting it as promoting European unity-cum-democracy while in fact it divides Europe into hostile national camps, by forcing its nations under a uniform monetary regime that suits only some of them, especially Germany, at the expense of others. Moreover, it not only entertains a technocratic conception of the way to European democracy, but also remains strangely vague on how a democratic Europe, reformed according to Habermasian principles on the foundations of the European Union of today, would differ from the present technocratic one.

Furthermore, the book also leaves more questions open than it answers on the status of European nations in a united democratic Europe and on the nature of the future democratic European entity, except that it rules out a supranational state $^{2}$ - even though at the same time, remarkably, it expects a democratically united non-state Europe to perform core state functions, like European 'selfassertion' in global politics (17) and imposing 'social justice' on the capitalist European economy (11). Moreover, it avoids the issue, central for Habermas's theory of an evolving moral universalism, of whether the future European construction will be distinctly European or, alternatively, anticipatorily cosmopolitan - in other words, whether united Europe will have a substantively fixed or a contingently moving border. It in addition assigns to Germany of all countries a leading role in the democratic de-nationalization of Europe (18ff.; pas$\mathrm{sim}$ ), a role it is to seek in order to protect itself and the world from a return of imperial 'power fantasies', by dissolving as a nation into an encompassing denationalized Europe. Among other things, this overlooks that the same monetary union which Habermas considers an indispensable stepping stone towards that Europa has already turned the Euroland economy into an extension of the German economy, under a really existing German hegemony dedicated to, of all things, spreading ordoliberal 
'reform' to the rest of Europe, to the considerable annoyance of some, if not all, of Germany's partners.

This being so, it cannot come as a surprise that nothing in Habermas's book prepares the reader for the powerful popular reaction currently observed in Europe to the wilful destruction of national sovereignty, national democracy and the national welfare state on which 'the European project' has in the past two decades embarked, in faithful execution of the functional imperatives of neo-liberalizing global capitalism. In Habermas's world, the only possible explanation for today's escalating crisis of European integration is cognitive and moral deficits on the part of both governments and the governed, while the only solution are stronger 'proEuropean' leaders, wherever they may come from (Germany?), ready to stick 'more Europe' to the reluctant masses. That this might end up producing even more anti-Europe - something that a growing number of observers, surely not all of them 'nostalgic fools' (see below), have for some time seen coming - is never even considered. Sadly enough, years of debate over the evolving empirical observables in Europe and the theories needed to make sense of them have had no impact on a political imaginary which, after all, must conceive of itself as dedicated to principles of discursive rationality.

The blind spots in Habermas's antinational Europeanism are interestingly linked to his system-theoretically neutered concept of capitalism. Having at some point in the evolution of his social theory granted immunity to a 'globalized' capitalist economy by redefining the interests vested in it into 'problems' calling for technically correct 'solutions', Habermas can treat really existing politics - the rough and tumble of local, regional, national collective interests, histories, languages, experiences, identities, hostilities, cultures, idiosyncrasies and passions - as non-substantial illegitimate impediments on the way to democracy as it should be: universalistic, dispassionate, global, deliberative, cooperative, and apparently without any need to override obstinate interests in the unlimited accumulation of capital by use of collectively mobilized power and legitimate force (that is, of the very state capacity that Habermas, for whatever reason, denies his European democracy). What remains at the end are normative prescriptions of rational-cum-moral cosmopolitan political conduct for which there is no real world out there that could live by them. One must be afraid that all a theory of this sort can do is move the theorist into a position of moral superiority in relation to a political reality that has no chance but being found guilty of failing to verify theoretical predictions that are in fact moral commands.

\section{WHY THE EURO?}

Among the puzzles in Habermas's writings on 'Europe' is that he never cares to explain why he insists on identifying the prospect of European democracy with, of all things, the European Monetary Union: a from the beginning profoundly compromised monetary regime that has in the few years of its existence critically divided Europe instead of uniting it (Streeck, 2015). In this, strangely enough, Habermas takes side with none other than Angela Merkel and her frivolous claim that, 'If the euro fails, Europe fails ${ }^{3}$ - identifying a 2000 year-old cultural and political landscape of grandiose jointly produced diversity with a trivial utilitarian construction that happens to serve above all the interests of the German export industries. ${ }^{4}$ No discussion is offered why bona fide European countries such as Denmark, Sweden, Norway, the United Kingdom (whose language we speak when we act as 'Europeans') and Switzerland have refrained from joining EMU, not to mention 
acknowledgement of the fact that after the Euroland experience they will not in any foreseeable future apply for membership (and neither will Poland, Hungary, the Czech Republic, etc.) - provided the lessthan-fully-common currency will survive the next decade, which is far from certain. Euroland is not Europe, and never will be, even if the euro was here to stay, Habermas and Merkel notwithstanding. Moreover, in addition to dividing Europe in Euroland and non-Euroland, the Euro has divided Euroland itself in debtor and creditor countries, allocating to Germany in particular the role of a despised economic taskmaster, ${ }^{5}$ while furthermore dividing member countries internally into 'proEuropean' and 'anti-European' camps, the latter rapidly increasing in strength especially where they are of a right-wing nationalist sort.

Why does Europe, or better: the Europe of Habermasian theory, need the Euro? Here Habermas, remarkably, comes out as an unabashed functionalist. Several times he refers to the common currency as a 'cunning of economic reason' (68) with respect to the Europeanizationthrough-denationalization of Europe - an institutional constraint that, once instituted, will, at the penalty of severe economic losses, force European countries to advance towards political, that is, economic, fiscal and social policy union, and to democratic union to boot, even if their citizens object to it. Since abandoning the Euro would remove that constraint and leave European integration without what Habermas sees as its unification engine, it must not even be considered, and any 'talk of a plan $\mathbf{B}^{\prime}$, for example in relation to the Greek calamities, must be discredited, if necessary morally. Obviously, what is lurking in the background of this is the so-called 'neo-functionalist' theory of European integration as developed by the GermanAmerican political scientist Ernst Haas (1958) out of long conversations with one of the engineers of post-war integrated
Western Europe, Jean Monnet. Its key concept is that of 'spillover', meaning the horizontal spread - at the time, of course, in no more than six countries! - of unified European institutions from sector to sector, driven by and compensating for the lack of a supranationally minded citizenry.

Of course, the problem with neofunctionalist integration theory is that it is profoundly technocratic, which is not surprising considering that it was inspired by someone like Monnet, a French technocrat who oversaw the early phase of European integration, in particular the European Community for Coal and Steel. For some time now it has dawned on most political scientists working on the subject that the era of neo-functionalism is over. As integration is penetrating deeper and deeper into the fabric of national societies, spillover can no longer be counted upon to move integration forward. Neofunctionalism, we now know, worked only under the 'permissive consensus' of the founding years, when nobody really cared what European elites were doing 'in Europe'. But, as integration progressed and as a result became politicized, further progress requires more than technocratic 'necessity' - not the behind-the-back functionalist reason of the economically inevitable, but political reason.

Here nations come in, and with them Habermas's stubborn denial of their factual existence as moral and economic communities of shared understandings and institutionalized solidarity, or in any case of their moral right to exist as such. Completely in accord with the Eurocrats, Habermas finds nations embarrassing, presumably not just for political reasons but also because they do not fit his theory of modernity, and wants them to go away as they might obstruct what he hopes will be the unstoppable progress of economic 'globalization' promoting moral cosmopolitanism. Where one might have expected a serious discussion of the relationship between national and supranational politics 
in Europe on the one hand and the domestication versus the liberalization of European capitalism on the other, yielding a fourfold table as sociologists have been used to since the days of Talcott Parsons, all one finds is unconditional partisanship for the non-national and supranational. Here Habermas does not refrain from aggressive polemics aimed at excluding those unwilling to subscribe to his views from the spectrum of legitimate opinion, as in a manifesto titled Wäh/t Europa! (Elect Europe!) issued in the run-up to the 2014 European Parliament elections by the late Ulrich Beck, with Habermas its first signatory, which warned against an 'anti-European revolution of the right and the left Right' (in German: 'eine antieuropäische Revolution der rechten und linken Rechten'). But morally disparaging national communitarian institutions and solidarities in the name of an undersocialized cosmopolitanism, and one disarmed in its relationship with capitalism by a refusal to assume the tasks and the burdens of a state, is dangerous. The repressed may powerfully return, and then in the distorted shape of a Marine Le Pen and consorts: of nationalist movements that will not confine themselves to insisting on sovereign powers to deal with their problems in their own responsibility, but will combine this with hatred of anyone they care to define as not belonging to their kind. I am afraid that Habermas and his opportunistic friends in Brussels and Berlin will to the very end and beyond refuse to understand that their brand of Europeanism was, and is, a potent cause of the hostile parochialism that is so frighteningly proliferating even in the most liberal and internationalized countries of Europe.

Not only may the cunning of economic reason fail to do its job, due to stubborn refusal on the part of citizens to see the light and say $B$ after their governors have said $A$ on their behalf. I leave aside for the moment the question if Habermas could consider such resistance to technocracy democratic. More importantly at this point, Habermas never doubts that imposing a common monetary regime on countries with different political economies and social structures does in fact reflect 'economic reason', not to mention asking whose reason it is that it reflects (Streeck, 2015). For Habermas, money is money, and all that matters is its territorial domain, the bigger - the more universalistic - the better. Extension of a legal tender's jurisdiction in the name of 'economic reason' is assumed to be so all-round beneficial that on its coattails a coterminous extension of political jurisdiction - a departure from Kleinstaaterei towards, apparently, something like Großstaaterei - must inexorably follow, 'nostalgic' (89) resistance from the uninitiated being nothing but 'foolish' (101). Comparison between the suffering of the Mediterranean countries inside Euroland and the prosperity of the Danish, Swedish, Norwegian and Icelandic economies - countries that have chosen to remain free to use monetary policy in the service of their respective niche strategies for the global economy ${ }^{6}$ - is not admitted into the evidence. This is probably because it might suggest that less economic universalism matching the constitutive particularism of really existing human societies might be a more democratic answer to our current political-economic predicaments than more political universalism trying to match the infinite universalistic advance of money and markets - the latter for Habermas apparently the predetermined course of historical evolution, normatively desirable and technically necessary at the same time.

\section{DEMOCRATIC LEGITIMACY FOR 'SYSTEMIC DEMANDS'}

Habermas's confidence in the cunning of technocratic reason replacing national 
particularism with European universalism raises the question of what exactly the fault is that he finds with the really existing European technocracy, and what he hopes will take its place when its 'lure' or, perhaps, its cunning? - will have done its work. But at this point, again, the argument remains hazy, although what is at issue would appear to be nothing less than the difference between capitalism as it is now and capitalism contained and constrained by democratic social and political powers. Instead, Habermas speaks of a 'transfer union' (9, passim), without discussing who is to transfer what, and how much, and to whom. More generally, he observes that

[a] technocracy without democratic roots would neither have the power nor the motivation to accord sufficient weight to the demands of the electorate for social justice, status security, public services and collective goods, in the event of a conflict with the systemic demands for competitiveness and economic growth. (11f.)

But would a technocracy with democratic roots? Habermas seems to believe that the political-economic problem of Europe is basically a lack of sensitivity to popular demands in European decisionmaking centres that could in principle easily be remedied if only such demands were given a constitutional opportunity to make themselves heard, for which a parliament devoid of a state would suffice. Moving electoral democracy from the national level, where rising interdependence has rendered it ineffective, to the European supranational level would, or so Habermas suggests, make 'systemic demands' once again malleable to human counter-demands, simply by enlarging 'the basis of legitimation' to match 'the expansion of steering capacities' (11). ${ }^{7}$

Is this in any way realistic? For Habermas, the enemy is not capitalism but technocracy, and only as long as its congenital insensitivity to popular sentiments endangers the project of European de-nationalization. In this perspective, the transfer of political-economic decision making in past decades to electorally unaccountable institutions, such as an independent central bank, appears as no more than a side-effect of honest efforts to resolve increasingly difficult problems of international interdependence. De-democratization did occur, but mostly by accident and oversight in the heat of a running battle with difficult problems of coordination, perhaps reinforced by deplorable although corrigible nondemocratic habits on the part of hardworking problem-solvers, but clearly not with a pro-capitalist neo-liberal intention or as a concession to growing capitalist power. Thus it can be healed, the 'systemic demands' of contemporary capitalism notwithstanding. Indeed ultimately, it is not capitalism that is the problem in Habermas's Europe, but its management. What is wrong with the Europe of monetary union, Habermas implies, is not that it is pro-capitalist, or subservient to capitalist interests, but that it is - contingently non-democratic, thereby subverting the struggle against the real enemy, nationalism. Democracy is to correct this by making the demands of ordinary people heard as decision makers attend to 'systemic demands', refilling the system's supply of legitimacy. No need to confront the increasingly insatiable demands of the profit-dependent classes for precedence of their interests over those of the rest of society. In fact class interests do not really appear in Habermasian European theory, only biased cognitions of decision makers in need of democratic correction. This disregards the fundamental insight of critical political economy that 'the economy' is fundamentally not about more or less enlightened management but about more or less manifest class conflict, in which the adversary of 'the people' is not technocracy but capital (Mouffe, 2005). 
Hidden behind what dresses up as systemic necessities, indeed as 'economic laws' and 'economic reason', are interests as shaped by evolving relations of economic and political power, today in particular the changing power balance between increasingly global capital and inevitably local labour. There is no way one can talk about European democracy without also talking about capitalism.

\section{Notes}

1 The last chapter in this sequence, Chapter 7, is a review of a book published by this author in 2013. The review is unenthusiastic enough in parts for it to be included in the following discussion. For an extensive response to it see Streeck (2013; English translation 2014).

2 Of course this has for several years now been the official Brussels position, where the would-be rulers of the 'ever closer union of the European peoples', while refusing to take part in the building controversy over what is the finalité of European integration, strictly deny that what they have in mind is a 'United States of Europe'. Obviously this is to pacify the citizens of member countries who in their vast majority find this prospect horrifying. Perhaps Habermas's renunciation of a state-building project may also be political rhetoric to mislead the uninitiated. In this case, however, one wonders if he has understood the other function of the recent anti-statism of Brussels, which is to reassure international capital that the new European entity will not undertake to domesticate it in the way the nation-state has tried to and may still return to trying.

3 Even though he is very well aware of all or most of the problems of the EMU. See 8 and passim.

4 In the only place where Habermas discusses this - in an interview with an Austrian weekly newspaper he refers to his personal 'knowledge of history and the political life experience of a German of my generation' to argue that 'it would be demoralizing if the currency union were to fail for clear reasons of national egoism' (69) - which, the context suggests, means that the Euro would fail, if it did, because of German national egoism, making it a German responsibility not to be 'egoistic' for the sake of European unity. That the Euro might fail because it would turn out to be an economic disaster for some of its member states while being a boon for others is not taken into consideration since, presumably, whatever economic problems it might produce could be cured by German altruism motivated by the haunting memories of the German past. Habermas also predicts that a 'failure' of the Euro 'would provide the starting signal for the right-wing populism that has undergone a revival in all of our countries' (ibid.). This misrepresents the causal relationship as it was and is the defence of the Euro that gave the 'starting signal' for 'antiEuropean', sovereigntist movements in several countries, where it was not least fear of German hegemony that led to popular demands, for example, in France, for the Euro to be rescinded rather than saved.

5 A sort of leadership it has now sought and found also in a second field, that of humanitarian charity, by masterminding the European 'refugee crisis'.

6 Note that Iceland, while hit hardest by the financial crisis, was able, having kept its own currency, to devise the probably most socially compatible solution to it (International Monetary Fund, 2015). Consider also the United Kingdom, where monetary sovereignty helped the country avoid what would otherwise have been an even more severe crisis.

7 Which, so Habermas in a surprising adaptation of European technospeak, would also, on top of it all, 'promote growth and competitiveness in the Eurozone as a whole' (28).

\section{References}

Haas, E.B. (1958) The Uniting of Europe, Stanford: Stanford University Press.

Habermas, J. (2013) Im Sog der Technokratie. Kleine Politische Schriften XII, Berlin: Suhrkamp.

International Monetary Fund. (2015) 'Iceland makes strong recovery from 2008 financial crisis', 13 March

2015, available at http://www.imf.org/external/pubs/ft/survey/so/2015/car031315a.htm, accessed 6 October 2015.

Mouffe, C. (2005) On the Political, London: Routledge.

Streeck, W. (2013) 'Vom DM-Nationalismus zum Euro-Patriotismus? Eine Replik auf Jürgen Habermas's', Blätter für deutsche und internationale Politik 58(9): 75-92. 
Streeck, W. (2014) 'Small-state nostalgia? The currency union, Germany, and Europe: A reply to Jürgen Habermas's', Constellations 21(2): 213-221.

Streeck, W. (2015) 'Why the Euro divides Europe', New Left Review 95(September/October 2015): 5-26.

\section{About the Author}

Wolfgang Streeck is Emeritus Director at the Max Planck Institute for the Study of Societies in Cologne. His most recent book is How Will Capitalism End? (Verso, 2015). 